\title{
CAMA
}

Centre for Applied Macroeconomic Analysis

\section{Benchmarking Macroprudential Policies: An Initial Assessment}

\section{CAMA Working Paper 60/2016 September 2016}

\author{
Domenico Lombardi \\ CIGI
}

\section{Pierre L. Siklos}

Wilfrid Laurier University

Balsillie School of International Affairs

CIGI and

Centre for Applied Macroeconomic Analysis, ANU

\section{Abstract}

In recognition of the severe consequences of the recent international financial crisis, the topic of macroprudential policy has elicited considerable research effort. The present study constructs, for 46 economies around the globe, an index of the capacity to deploy macroprudential policies. Building on elements that have been the subject of recent research, we develop an index that aims to represent the essence of what constitutes a macroprudential regime. Specifically, the index quantifies: (1) how existing macroprudential frameworks are organized; and (2) how far a particular jurisdiction is from reaching the goals established by the Group of Twenty (G20) and the Financial Stability Board (FSB). The latter is a benchmark that has not been considered in the burgeoning literature that seeks to quantify the role of macroprudential policies. 


\title{
Keywords
}

Central banks, Financial Stability Board, index, macroprudential policy, policy framework

\author{
JEL Classification
}

E32, E42, E58, E02, F02

\section{Address for correspondence:}

(E) cama.admin@anu.edu.au

\section{ISSN 2206-0332}

The Centre for Applied Macroeconomic Analysis in the Crawford School of Public Policy has been established to build strong links between professional macroeconomists. It provides a forum for quality macroeconomic research and discussion of policy issues between academia, government and the private sector.

The Crawford School of Public Policy is the Australian National University's public policy school, serving and influencing Australia, Asia and the Pacific through advanced policy research, graduate and executive education, and policy impact. 


\title{
Benchmarking Macroprudential Policies: An Initial Assessment ${ }^{*}$
}

\author{
[This draft: August 2016] \\ Domenico Lombardi, CIGI \\ Pierre L. Siklos, WLU, BSIA, CIGI, and CAMA
}

*This is a CIGI-sponsored research project. The opinions in the paper are those of the authors and not the institutions that supported this research. Domenico Lombardi is Director of the Global Economy program at CIGI, Pierre Siklos is a CIGI Senior Fellow, and Professor of Economics at Wilfrid Laurier University and the Balsillie School of International Affairs. Samuel Howorth provided excellent research assistance. Part of the research was conducted while Siklos was a W. Glenn Campbell and Rita Ricardo Campbell National Fellow at the Hoover Institution, Stanford University, whose hospitality is gratefully acknowledged. We are grateful for the constructive comments from Malcolm Knight and two anonymous referees. Previous versions were presented at $6^{\text {th }}$ Annual Conference, "Monetary and Financial Shifts: Challenges and Possible Outcomes" of the Central Reserve Bank of Peru, as well as the CIGI-Oliver Wyman conference, "Unconventional Monetary Policies and Financial Stability: Implications for Banks and Financial Markets." We are also grateful to the BIS for access to a database of central bank legislation and organization charts. A modified version of this paper is forthcoming in the Journal of Financial Stability. 
In recognition of the severe consequences of the recent international financial crisis, the topic of macroprudential policy has elicited considerable research effort. The present study constructs, for 46 economies around the globe, an index of the capacity to deploy macroprudential policies. Building on elements that have been the subject of recent research, we develop an index that aims to represent the essence of what constitutes a macroprudential regime. Specifically, the index quantifies: (1) how existing macroprudential frameworks are organized; and (2) how far a particular jurisdiction is from reaching the goals established by the Group of Twenty (G20) and the Financial Stability Board (FSB). The latter is a benchmark that has not been considered in the burgeoning literature that seeks to quantify the role of macroprudential policies.

Keywords: Central banks, Financial Stability Board, index, macroprudential policy, policy framework

Domenico Lombardi, dlombardi@cigionline.org

Pierre L. Siklos, psiklos@wlu.ca, www.pierrelsiklos.com

JEL Classification codes: E32, E42, E58, E02, F02 


\section{Introduction}

In the past several years a considerable amount of research effort has been devoted to the topic of macroprudential policy. While the term 'macroprudential' apparently dates back to the 1970s (Barwell 2013), the Bank for International Settlements (BIS) championed the push for macroprudential regulation as of last decade (e.g., Borio and White 2004). One of the early supporters of the development of a macroprudential framework, Andrew Crockett, former General Manager of the BIS, put it in the following terms: "Strengthening the macro-prudential orientation of the regulatory and supervisory framework is important because of the costs and nature of financial instability. The main costs take the form of output losses. The nature of the processes generating instability puts a premium on a macro-prudential conception of economic behaviour" (Crockett 2000).

In contrast to the management and staff of the BIS, most active policy makers and academics made few references to macruprudential regulation until the global financial crisis (GFC) of 2008-9. The unexpected interconnections, vulnerabilities, and contagion that marked the crisis underscored the fundamental importance of developing comprehensive macroprudential policy regimes. Yet, more than seven years after the crisis the meaning of the term 'macroprudential regulation' remains "obscure" (Barwell 2013), its motivation is imperfectly understood (e.g., Claessens 2014), and its effectiveness is still much debated (e.g., Galati and Moesner 2014). Although Kevin Warsh, a former member of the US Federal Open Market Committee (FOMC), referring to macroprudential policy, remarked in 2014 that "There remains precious little economic literature and policy practice to provide informed guidance" (op. cit., pg. 77), over the past couple of years there has been a surge of theoretical and empirical studies on the subject. Nevertheless, there is still little agreement on the ingredients of a macroprudential policy framework, unlike the case of monetary policy where there is greater consensus on what defines, for example, an inflation targeting regime. The principal motivation of this paper is to identify some key empirical indicators of the current state of the macroprudential framework in each of the 46 economies under review, and to make a preliminary assessment of whether they are empirically linked to the macroeconomic and financial variables that are commonly seen as closely associated with maintaining financial stability. 
Researchers and policy makers confront several challenges in tackling the subject. First, unlike monetary policy, which can be explained or summarized via rules of thumb such as the Taylor rule (Taylor 1993), there is nothing that comes close to a rule-based reaction function for implementing macroprudential policies. Indeed, it seems that this form of policy making is the antithesis of following clear cut policy rules, especially since macroprudential policies need to be designed to operate asymmetrically in the upswing and downswing of the financial cycle (McDonald 2015). To illustrate the intricacy of the macroprudential state of play, consider the 'alphabet soup' of programs the financial crisis produced in attempting to mitigate financial system-wide distress (viz., TARP, LSAP, QE, OMT, FLS, to name just a few). ${ }^{1}$

Second, burdening established policymaking institutions in each country with new macroprudential responsibilities confronts the well-founded concern, expressed long ago by Brainard (1967), that one ought to be conservative in deploying new policy instruments that could have unintended consequences. The objective of monetary stability is to preserve the purchasing power of the domestic currency by ensuring that prices are relatively stable. The objective of financial stability, however, is to ensure that the complexity and interconnectedness of the financial system, and the tendency for financial market behaviour to create financial boom and bust patterns, do not produce large negative externalities for the real economy.

Third, attempts by global institutions such as the Financial Stability Board (FSB) to implement comprehensive assessments, analyses, and regulatory proposals, with the objective of reining in the financial system's tendency to create recurring crises, creates complexity that makes it more challenging for policy makers to communicate how they intend to stabilize the world financial system. If the objectives are unclear, and the means through which they are to be attained are problematic, then communication becomes extremely difficult. Nevertheless, these developments also highlight that an evaluation of the effectiveness of macroprudential policies involves a mix of institutional, economic, and financial elements.

\footnotetext{
${ }^{1}$ TARP (Troubled Asset Relief Program) and LSAP (Large Scale Asset Purchases) by the US Fed and Treasury; QE (quantitative easing) and OMT (Outright Monetary Transactions) by the European Central Bank; and FFL (Funding for Lending) by the Bank of England.
} 
The present study is an effort to provide, for 46 economies, ${ }^{2}$ an empirical index of the capacity to deploy macroprudential policies. Our aim is to quantify how existing macroprudential frameworks are organized by incorporating indicators of how far a particular jurisdiction is from meeting the goals set by the FSB and the Group of Twenty (G20). We believe this benchmark has been largely overlooked in the literature until now.

Our proposed index also includes several other elements that are relevant for assessing the capacity of policy makers to deliver effective macroprudential policies. These elements include: (1) the availability of macroprudential instruments, (2) the specification of the financial stability mandate, and (3) the division of institutional responsibilities between the central bank and other agencies. It is important to note, however, that the aggregate index of these factors is intended to capture the existence of this policy framework; we do not attempt to evaluate how effective the framework is likely to be in maintaining financial stability - that will only be possible after these frameworks have been in place for a period of time (e.g., also see Masciandaro and Volpicella 2016).

Our work is in the vein of recent attempts, for example, by Lim et al. (2013b), to evaluate the impact of macroprudential policies. However, unlike their empirical measure, ours is broader in scope and takes into account more explicitly the work done by the FSB. Moreover, while the economies that were most impacted by the GFC tend to have made relatively more progress in responding to macroprudential concerns, so have others not directly impacted by the crisis. Hence, while, as in Lim et al. (2013b), macroprudential policies can be country-specific, there is a global element that must not be ignored.

The rest of the paper is organized as follows. The next section provides a literature survey. As the extant literature covers a wide variety of topics, we focus on issues that are most germane to the paper. ${ }^{3}$ In section 3 we detail our attempt to develop an empirical index of the

\footnotetext{
${ }^{2}$ The economies covered by our analysis include a mix of advanced and emerging market economies. A complete list shown in Table 2a.

${ }^{3}$ Barwell (2013) is a comprehensive account of the origins, development, and theoretical aspects dealing with macroprudential policies, although it leans towards the UK perspective (see below). More general surveys that examine the motivation and deployment of macroprudential policies to date include Claessens (2014) and Galati and Moessner (2011, 2014).
} 
components of a macroprudential regulatory framework, and a ranking for the 46 economies as of January 2015 concerning their readiness, both institutionally and relative to the criteria established by the G20 and the FSB, to meet the attendant financial risks they faced. Section 4 discusses the versions of our index that we estimate and reports our key findings. Based on the results for this indicator we then illustrate empirically, in a cross-sectional setting, how our index correlates with some macro, financial and institutional measures routinely used in the relevant literature. Our key conclusion from this cross-sectional work is that credit growth is a significant determinant of the capacity of the existing macroprudential framework. Section 5 concludes and offers some policy implications.

\section{Literature Review}

Put simply, macroprudential policy is intended to assist with the maintenance of financial stability. ${ }^{4}$ Financial stability requires two ingredients (e.g., Galati and Moessner 2011): the financial system must be robust to external shocks (e.g. Allen and Wood 2006, Padoa-Schioppa 2003); and it must be resilient to shocks originating from within the financial system (Houben et al. 2004), and to "normal-sized" shocks (Borio and Drehman 2009). For example, this motivates Angelini et. al. (2014) to extend a DSGE model that incorporates financial frictions. Time-varying capital requirements, which serve as a macroprudential instrument can be stabilizing under certain circumstances. In particular, knowing the source of the economic shock is critical as is the degree of cooperation between monetary policy and the goal of financial system stability. Ghilardi and Peiras (2016) adopt a similar framework but are interested in how capital flows to emerging market economies can prevent financial instability also through the application of a macroprudential instrument.

As Carney (see Yueh 2015), among others, has pointed out that theory has yet to catch up with practice in the conduct of macroprudential policies. There have, of course, been some recent important contributions (e.g., see Freixas et. al. 2015, Leduc and Natal 2015, and also Bank of

\footnotetext{
${ }^{4}$ The online appendix provides examples of how different central banks define the concept of financial system stability. Galati and Moessner (2011) point out that since 2008, usage of the term "macroprudential" in speeches by central bankers (e.g., Shirakawa 2009, and Kohn 2009) has risen markedly, paralleling a sharp rise in academic research.
} 
England 2009, 2015). Nevertheless, our concern is with an empirical evaluation of the characteristics of existing macroprudential regimes at the present time.

Only two studies, to our best knowledge, have attempted to quantify macroprudential policy frameworks. Lim et al. (2013b) rank institutional set-ups on an integer scale from 1 to 4, based on the respective roles of central banks and governments in macroprudential regulation. ${ }^{5}$ The authors conclude that small open economies tend to have a more integrated approach, with the central bank ordinarily the competent authority, while more complex economies leave a larger role for the government. They also find that a unified framework - where a single institution has the primary responsibility for the objective of financial stability - is more likely to employ macroprudential policy instruments than frameworks that require coordination among several separate national or supranational agencies with distinct mandates are responsible for financial stability.

Cerutti et al. (2015) create a time series indicator of the effectiveness of known macroprudential tools in dampening credit cycles for 119 countries from 2000 to $2013 .{ }^{6}$ The authors find that macroprudential tools are effective at reducing credit growth, but their effectiveness varies by instrument, by country, and the state of the credit cycle. Prior to the GFC, it is almost certainly questionable whether the tools apparently available were primarily intended to deal with macroprudential concerns as they are understood today.

Our own indicator is broader in scope than extant ones and, unlike Lim et al. (2013b) or Cerutti et al. (2015), takes explicit account of efforts by the FSB to establish some common rules of conduct and metrics that countries are expected to use in fashioning a macroprudential

\footnotetext{
${ }^{5}$ Other attempts at creating indexes for specific applications (i.e., applied to housing or a particular region of the globe) include Kuttner and Shim (2013) and Zhang and Zoli (2014). Lim et al. (2013a) focus on current practices in Asia. The index is an aggregation of the following characteristics: who is in charge of macroprudential policy, the role of government in the framework, decision-making and control over macroprudential instruments, and whether a coordinating body exists to carry out macroprudential policies.

${ }^{6}$ Theirs is an attempt to evaluate the effectiveness of 12 macroprudential instruments based on the timing and use of these instruments and their connection to credit growth developments in the economies investigated.
} 
framework. ${ }^{7}$ We also make extensive use of governance information collected by us and the BIS as this is a critical, though unsettled, element in designing a macroprudential framework (also see Masciandaro and Volpicella 2016). Nevertheless, we conclude, as did Cerutti et al. (2015), that there exists a robust empirical link between macroprudential framework capacity and credit growth.

The central bank's role may vary from being a member of a macroprudential policy board (such as the Financial Stability Oversight Council in the US), to providing the analytical basis for monitoring systemic risks (such as in the case of the European Central Bank), to being the single entity responsible for macroprudential analysis and policy implementation (as in the case of the Bank of England and the Reserve Bank of New Zealand).

There is potentially a high degree of interaction between macroprudential and monetary policy. Both influence the supply and demand of credit and risk appetites (IMF 2013b). For example, looser monetary policy may, over time, create an incentive for both borrowers and lenders to become more leveraged, which creates vulnerabilities to adverse shocks (Adrian and Liang 2014). Central banks are typically also at the forefront in combatting financial crises.

A potential counterargument for assigning a financial stability goal to the central bank is that it can weaken perceptions of the commitment to price stability, and thus destabilize inflation expectations (Agénor and da Silva 2014). Moreover, there is a risk, unless the lines of authority between elected and appointed officials are laid out precisely, that macroprudential policies can appear to be politically motivated or draw the central bank into the realm of distributive policies, both of which are frowned upon by supporters of the principles of central bank autonomy and democratic accountability (e.g., Goodfriend 2012, Tucker 2014b).

Various operational structures for monetary and macroprudential policy have been discussed in the literature. Macroprudential policy targets particular sectors through a granular approach (Schoenmaker 2014) whereas monetary policy is often regarded as a blunt instrument for

\footnotetext{
${ }^{7}$ Though only for 19 economies. These data apply to G20 members only. Also, correlations between the Lim et al. (2013b) or Cerutti et al. (2015) indexes and ours are small and statistically insignificant. Details are available from an unpublished appendix.
} 
pursuing financial stability (e.g., Eichengreen et al. 2011). Hence, macroprudential and monetary policy should work independently of one another (Goodhart 2014, also see Tucker 2014a). There are indeed strong complementarities between monetary and macroprudential policies (e.g., IMF 2013a), and monetary policy can play an important role in addressing the "procyclicality" of the financial system (Borio and Drehmann 2009). Critics argue, however, that this approach may, on average, produce tighter monetary policy (Agur and Demertzis 2012).

Alternatively, cooperation may be preferred. Monetary policy and macroprudential policy are interdependent. Compromise may be required should macroprudential policies run into political constraints or lobbying pressures (Dell'Ariccia et al. 2012; Portes 2014). Furthermore, macroprudential policy tools should be sufficiently different from the tools used by the monetary authority to prevent coordination problems among policy-makers (De Paoli and Paustian 2013). The role of cooperation between policy makers is also at the heart of the model developed by Angelini et. al. (2014).

The 'coordinated' approach brings relevant authorities (e.g., central banks and banking supervisors) together in a cooperative agreement (in the form of a policy board or memoranda of understanding) with the aim of achieving financial stability by relying on each institution's respective instruments and expertise (Eichengreen et al. 2011). In contrast, the 'single entity' approach entrusts one institution with multiple mandates and various instruments with which to achieve them.

The coordinated approach can lead to conflicting opinions and strategies (Ingves 2011). Furthermore, a central bank, which is typically independent from government and other institutions, may not look favourably on coordinating its policies with other institutions. There are potentially some governance drawbacks from the coordinated approach: it may weaken accountability if authorities can divert responsibility, it may also increase the risk of inaction (Knot 2014; Ingves 2011), and there is always the risk of inter-agency rivalries or conflicting mandates getting in the way of coordinated action on perceived risks to financial stability.

The single-entity approach has some advantages. It creates clarity of responsibility in identifying risks and implementing policies (IMF 2011), and is administratively simple and cost-minimizing 
(Anand et al. 2014). Furthermore, it serves to eliminate regulatory gaps and ensure policy consistency, thereby reducing regulatory arbitrage (Anand et al. 2014; see also Pan 2010). However, the central bank is not suitable to be the unified authority in all cases. Indeed the financial regulatory environment is a very complex system, and central banks across policy jurisdictions have extensive ranges of responsibilities, powers and trade-offs (Ingves 2011). Since there is no resolution to this debate this feature is reflected in our index, to which we now turn.

\section{A Macroprudential Capacity Index: Composition and Definitions}

Our proposed index incorporates over 30 elements considered to be part of a macroprudential framework. We allocate them to eight categories: (1) the authority the central bank has in carrying out macroprudential policies; (2) the number of entities responsible for the maintenance of financial stability and their mandates; (3) the existence of deposit insurance scheme; (4) the degree of transparency and accountability in the macroprudential regime; (5) the governance of the macroprudential framework; (6) how resorting to macroprudential instruments influences the monetary policy transmission mechanism; (7) how far the current macroprudential regime is from the FSB/G20 recommendations (timeliness and responsiveness to regulatory reforms); and (8) how quickly policy makers respond to the need to implement FSB/G20 measures intended to ensure financial system stability. Below, we discuss each grouping in turn.

Table 1a provides a description of the contents of the eight categories used in defining the index. ${ }^{8}$ With one exception (see Table 1 a below) the index is designed such that a rise in the value of a component implies an increased capacity of the macroprudential framework. Table $1 \mathrm{~b}$ provides the coding details of each element across the eight categories that are aggregated to produce the index. Table $2 a$ provides a variety of versions of the index. Some versions are restricted to FSB member countries (i.e., G20 economies), and others are sensitive to whether we include changes in governance structures since the GFC.

\footnotetext{
${ }^{8}$ A detailed spreadsheet containing the data, and tables giving the index values for each country for each category separately, is available as an online appendix.
} 
The benchmark index values shown in Table $2 a$ are unweighted. ${ }^{9}$ One version of the index considers what happens when we exclude organizational changes that had taken place in central banks by $2011 .{ }^{10}$ Since many central banks have acquired more responsibilities over financial stability since the GFC we are interested in incorporating this feature into the index. We assume that, by 2011, many of the reforms introduced since the GFC were reflected in the organizational structure of the central banks examined. A rise in the profile of financial stability within a central bank would therefore reflect the increased weight and additional resources devoted to this function. Therefore, it is natural to consider this aspect for inclusion in an index of macroprudential capacity. ${ }^{11}$

Next, as a test of the sensitivity of our indicators to a weighting scheme, we estimate a version of the index using weights shown in the last column of Table 1a. We also consider versions of the index where, in turn, the index either favours or penalizes centralizing authority over macroprudential policies. In the empirical section we consider other types of weights based on a variety of economic, financial and institutional characteristics of the economies considered.

To facilitate cross-country comparisons, Table $2 \mathrm{a}$ provides the raw scores of the index while Figure 1 normalizes index values to range between 0 and 1 . The index that includes only FSB member economies (i.e., the $\mathrm{G} 20$ members) permits a focus on those economies that have been at the forefront of reform efforts aimed at promoting the creation of a coherent macroprudential framework.

Before describing the results in the following section, we provide an explanation and justification for the categories listed in Table 1a. The first category of the index captures the

\footnotetext{
${ }^{9}$ Within the different groups listed in Tables $1 a$ and $1 b$, group one has 4 elements and a highest observed value of 11, group two has 11 elements and a highest value of 16.5, group three has 1 element and a highest value of 1 , group four has 6 elements and a highest value of 3, group five has 5 elements and a highest value of 10, group six has 1 element and a highest value of 1, group seven has 3 elements and a highest value of 3.5 and group eight has one element and a highest value of 6 .

${ }^{10}$ This is the most recent year when the BIS collected central bank organigrams at the time of writing.

${ }^{11}$ This part of the index is an aggregation of several governance characteristics. They are: the size of monetary policy and financial stability committees, whether the two committees are distinct or not, any changes in the number of senior departments in a central bank since 2011, and whether or not a distinct financial stability department exists. If the answer to the last point is yes then we ask whether the department is at the same level in the organizational chart as the department responsible for providing input into monetary policy and whether the two departments report to the same deputy governor or not.
} 
number and availability of macroprudential instruments and the central bank's ability to deploy those instruments, taking into consideration the legal basis of this authority.

The second category captures the extent to which there is a formal understanding of the mandate for financial system stability and the central bank's role in maintaining it, including whether the macroprudential remit is explicit. For example, whether the responsibilities are defined in statute provides some indication of the degree to which a concern about the maintenance of financial system stability is regarded as being on an equal footing with responsibility for the conduct of monetary policy. This category also includes the extent to which the responsibility to act is assigned primarily to the central bank. As previously discussed, there continues to be controversy over how much responsibility the central bank has in the macroprudential realm. Accordingly, we create two versions of our index. In one it is assumed that separate authorities working collectively improves the capacity of the macroprudential framework to deliver financial stability. However, it must be recognized that for reasons discussed in the literature review, the opposite can also be true. Therefore, we also show what happens to the index values when, instead, giving the authority over macroprudential policies to the central bank alone improves the capacity of the macroprudential framework. ${ }^{12}$

The next category considers specific areas of policy such as the banking system and monetary policy as well as the governance of macroprudential frameworks. The existence of a deposit insurance scheme, its overall structure and generosity may well have spillover implications and influence the costs of maintaining financial system stability. As a result, deposit insurance fits the definition of a macroprudential instrument.

Transparency and accountability have become the sine qua non of best practices in the conduct of monetary policy. Similarly, one would expect that central banks will want to explain their

\footnotetext{
${ }^{12}$ We are grateful to a referee for suggesting this variant. The problem encountered here is reminiscent of the debate many years ago over whether it is preferable to separate financial supervision from central banking (Goodhart and Schoenmaker 1995). The decision to separate the functions in the UK (Bank of England versus the Financial Supervisory Authority) was later seen by some as a mistake (e.g., see Whelan 2012). The 'single peak' model adopted by the UK, following the GFC, contrasts with the twin or 'multiple peaks' approach followed in the US. Clearly, there are strong differences of opinion over which model works best. Interestingly, Masciandaro and Volpicella (2016) report that a central bank that has some microprudential responsibilities is also likely to acquire responsibility for macroprudential policies.
} 
stance vis-à-vis macroprudential policies and their place in the overall responsibilities assigned to the central bank; as well as highlighting the risks to financial stability and the sources of instability. To do so, we quantify how intensively the central bank raises issues surrounding the implementation of its macroprudential regime in verbal and written form. ${ }^{13}$

The extent to which the financial crisis altered the responsibilities of central banks should be reflected in whether and how the central bank's administrative structure has changed. This is where central bank governance plays an important role, especially when financial system stability is an additional responsibility assigned to the central bank and listed under category 5 . This may be reflected in a variety of forms, from an increase in the size or number of policy making committees to a rise in the number of departments in the central bank. An increase in one or both of these organizational elements is likely to reflect a greater capacity of the central bank to deal with financial stability questions.

The role a macroprudential regime plays in the central bank's views about how the transmission mechanism of monetary policy functions is potentially an important ingredient in evaluating the monetary authority's ability to cope with financial shocks that threaten the stability of the financial system. This is represented as category 6 in the index. Nevertheless, here too it must be recognized that central banks debate how the implementation of macroprudential versus policy interest rate changes influence the monetary policy transmission process (e.g., see Bank of England 2015).

The final two categories of the index (7 and 8) explicitly recognize that the FSB has taken on a pivotal role in developing standards for the implementation of macroprudential policies, as well as providing guidance about best practices in the area. Hence, we sought to quantify how far the economies in our sample are from fulfilling the recommendations made by that body. Indeed, in partial recognition of this development, the weighted version of the index assigns a weight of $1 / 4$ of the total to these two categories combined. This is measured by quantifying a

\footnotetext{
${ }^{13}$ Here we simply count the number of speeches and press releases with macroprudential (or a similar expression) in the title, and divide the number by 12 to obtain average monthly values for each central bank. Additionally, we assign a value to the publication of a regular financial stability report (1), if there is a macroprudential 'section' in those reports (0.5), if another authority publishes an FSR or FSR equivalent (0.5), and if those have a macroprudential 'section' (0.25).
} 
country's 'distance' from fully adopting FSB recommendations as well the timeliness of its implementation of the required changes. Recommendations that are ignored for long periods of time are less likely to be implemented and may well degrade the quality and effectiveness of a macroprudential regime - so the longer policy makers take to implement FSB recommendations the lower is the value of the index. Put differently, the less aligned a country's macroprudential policy framework is with the FSB's recommendations, the lower is the effectiveness of that macroprudential framework likely to be.

It is unlikely a priori that all of the categories are equally important in determining the success of a macroprudential regime, so any attempt to attach weights to the various categories is also likely to be somewhat ad hoc. Nevertheless, the literature suggests that the most frequently debated questions are: the agency or institutions with authority over macroprudential policies, the specifics of the mandate, the availability of macroprudential instruments, and the flexibility of their implementation.

Since the FSB has been given the authority to formulate a framework that is intended to maintain financial stability, it is reasonable to place a substantial weight on its efforts. Because it is unclear how important many of the remaining categories are, we attach equal, but relatively lower, weights to them. However, we attach the lowest weight to categories 3 and 5 because deposit insurance predates the GFC, while our knowledge of the interaction between monetary and macroprudential policies is at a sufficiently early stage to weight these categories below the others (e.g., Bank of England 2015). In the results section we consider other examples of cross-country weighting schemes using alternative macroeconomic and financial indicators.

\section{Macroprudential Indicator: Performance}

\subsection{Macroprudential Index Scores}

Figure 1 displays a bar chart showing two versions of the normalized index scores. They are: (1) aggregating all of the categories (top bar chart) and, alternatively (2), adding the impact of 
organizational changes in central banks since 2011 (bottom bar chart). ${ }^{14}$ All calculations include several Eurozone economies as well as the European Union (EU). The higher the indicator the greater the capacity of the macroprudential framework and, at least in terms of the FSB/G20 recommendations, the more resilient the framework is for managing the risks of financial instability. As noted previously, and to ensure comparability, the indicator shown has been normalized so that the values range between 0 and 1 .

Table 2a shows the raw scores for the index. These clearly reflect, among other factors, the combined effects of the size of their economies (e.g., with the US, the UK, and the EZ being the largest) and the degree to which these economies are exposed to financial shocks (e.g., Saudi Arabia and Colombia being relatively less exposed). Moreover, there is considerable variety in the scores even among Eurozone economies, ranging from a low of 9 (Finland) to a high of just over 20 (Portugal). Adding the effect of organizational changes since 2011 either has no impact on the overall score (21 of 46 economies) or raises the score (18 economies). In most cases the changes are small but there are a few notable exceptions (e.g., Switzerland, India) which may reflect idiosyncratic responses to the increased emphasis on financial stability while the slight drop in the US captures the modest attempt at decentralizing authority following passage of the Dodd-Frank reform legislation. Scores are slightly lower for most economies when FSB-only members are considered and this is a reflection of the differences in the speed of response to FSB reform recommendations. The cross-country correlation between the weighted and unweighted index is very high (0.97), an indication that the weighting scheme does not alter considerably our interpretation of the results. Table $2 \mathrm{~b}$ provides the raw scores for each one of the eight categories described in Table 1. It is interesting to note that whereas almost all economies provide deposit insurance, only a little over a third (16 of 46 ) describe the role that macroprudential policy plays in the monetary policy transmission mechanism. As noted previously, this area is at a relatively early stage of development.

\footnotetext{
${ }^{14}$ The year 2011 is chosen because this represents the year the BIS surveyed its membership to obtain organizational charts. We also performed the calculations using changes since 2001 (not shown). The first measure can be said to represent capacity of sorts post-crisis while the second set of measurements reflects changes since before the GFC. Although the aggregate scores are different depending on whether we use 2011 versus 2001 as the benchmark the rank order of the aggregates is largely unchanged. Hence, we only discuss the results based on the 2011 calculations.
} 
Figure 1 suggests considerable diversity in the aggregate scores, regardless of whether we exclude organizational changes in central banks. Several interesting findings emerge. First, it is noteworthy that Ireland, one of the hardest-hit economies among Eurozone member countries in the past few years, earns an index value that is one of the highest among the 46 economies sampled. ${ }^{15} \mathrm{~A}$ comparison of the top and bottom portions of the figure also reveals that the EU's score exceeds that of the US, but only when organizational changes at the ECB are included. In any event, differences between the two economies are very small. EU member countries have not only increased the burden of macroprudential policies on the European Central Bank but have also given a boost to the EU in its oversight role in these areas. ${ }^{16}$ Finally, it is also worth noting that our aggregate macroprudential index is, generally speaking, related to the size and impact of the various financial crises since 2008. Hence, the US, the UK, and the EU have higher scores on this measure, as do several Eurozone economies (e.g., Ireland, Portugal, and Germany) while relatively financially unscathed economies such as Australia, Canada, India and Brazil display lower scores. Of course, there are exceptions such as Korea and Japan who were, of course, impacted by the GFC but less so perhaps than, say, the US.

Of course, aggregate measures can hide some interesting differences that can only be understood by looking at some of the individual categories of the index. Figure 2 plots the normalized scores for four select categories. The top left portion of the figure is a measure of the institutional 'distance' of each national macroprudential framework relative to the FSB/G20 recommendations as of 2014. For this reason only data for the G20 economies are shown. The higher are the bars in this figure the smaller the distance to the FSB's recommendations. Hence, the US, the UK, and the EU (actually the Eurozone or EZ), arguably the economies that were most directly affected by the GFC, have put into place macroprudential regimes that are closest to the ones deemed desirable by the FSB/G20. This is likely due, at least in part, to the fact that

\footnotetext{
${ }^{15}$ Because of the nature of the calculations we cannot attach statistical significance to the differences. We should also note that we considered adding Greece to the sample but concluded that there was too little data available to permit a meaningful comparison with the other economies in the dataset.

${ }^{16}$ Aggregate measures based on the 2001 organizational charts of central banks reveal quite clearly that Eurozone member country central banks have shrunk in size. Much of the reduction appears to have taken place before the crisis, that is, between 2001 and 2011.
} 
its three largest members, namely France, Germany and Italy, also have higher scores than most G20 counterparts. ${ }^{17}$

Brazil, India and China all score relatively low. This could be because these economies did not directly suffer from the GFC, as did the larger economies in our sample. Alternatively, these same economies do not have as well developed financial systems or have controls in place that have allowed them to approach conformity with FSB/G20 recommendations at a slower pace. In contrast, the other members of the BRICS score much higher, perhaps for the same reason or, in Russia's case, because centralization of authority made it easier to accomplish the necessary reforms.

The top right hand side bar chart in Figure 2 plots the response time - i.e. an index of the time taken to conform to FSB/G20 recommendations - using 2008 as the benchmark for calculating a measure of timeliness. Other things equal, it is assumed that a faster response time, here a smaller value for the index, translates into a more effective framework for dealing with macroprudential problems. Response times are measured in years. Overall, the data suggest that the economies closest to fulfilling the policies recommended by the FSB are also the ones that have responded in a more timely manner. Nevertheless, the sheer size of the task of building a macroprudential regulatory framework is also evident, as the larger economies must not only deal with the added complexities associated with sophisticated financial systems but also take into account the cross-border implications of their policies (e.g., the US, the Eurozone, the UK, and China).

Turning to governance issues, namely the extent to which different institutions are responsible, or accountable, for using the available macroprudential instruments, the data bring into clear focus some differences (bottom left-hand bar chart), notably among the UK, the US and the EU. The reason is that, in one interpretation, the indicator is set up such that if all power is concentrated in the central bank alone, the score is lower. Alternatively, the indicator penalizes the absence of centralization in assigning responsibility for macroprudential policies. As a

\footnotetext{
${ }^{17}$ The detailed scores for the case where the index is improved depending on one's views about whether it is preferable to centralize authority with the central bank is also included in the online appendix.
} 
result, the UK does badly in one view because the Bank of England has considerable authority to carry out all forms of macroprudential policy making. In contrast, the US, where power is more diffused, scores better. The roles are clearly reversed when the interpretation of the governance question changes. This is most clearly seen by comparing the UK and the US cases. The same holds for the Eurozone when authority is not centralized. Most of the Eurozone economies do not stand out because, since the Eurozone sovereign debt crisis erupted, authority has tended to shift to the EU, the ECB, or both. Otherwise, with a few exceptions, large cross-country differences are not apparent possibly reflecting the fact that, on balance, policy makers adopted different forms of decentralization in the governance of macroprudential frameworks.

Finally, the bottom right hand portion of Figure 2 attempts to measure the degree or transparency and accountability of the macroprudential framework in each jurisdiction. According to our index, Germany, the UK and the EU stand out as the best performers. This may suggest that frameworks which are somewhat more centralized may be more accountable and transparent. Correspondingly, the US scores less well, perhaps because the regulations needed to implement the Dodd-Frank reforms are not fully in place or because the US, which emerged from the crisis earliest among these three economies, has shown a declining appetite for continued reform as the financial crisis has receded from view.

There is no unique way of aggregating the individual characteristics of the index. A view of how the individual characteristics add up to a single normalized index can also be developed using alternative weighting schemes based on the desired criteria. Figure 3 gives an idea of the range of values that such a normalized index can take depending on which of a total of seven weighting schemes is chosen. ${ }^{18}$ The possible weighting schemes suggested by our analysis include: the relative size of the economies, the type of exchange rate regime, central bank transparency, and how open capital accounts are or the incidence of capital controls in the economies examined. Generally, our indicators are robust in the sense that irrespective of the

\footnotetext{
${ }^{18}$ Since these weights are possibly less ad hoc than the ones assumed in Table 1a we omit that case in constructing the bar chart in Figure 3. The chart for the case where macroprudential authority is centralized is shown in the online appendix.
} 
weighting scheme that is used, the relative rankings of countries are largely unaffected. For example, the US and the Eurozone consistently possess the greatest capacity to deploy macroprudential policies. That said, however, the results suggest that the capacities of the BRICS economies (see Figure 1) to deliver macroprudential policies are highly sensitive to how the indicator is weighted. Of course, these observations reflect the fact that many variables potentially interact with existing specifications of macroprudential frameworks, which can impact their capacity to deal with financial shocks emanating from various sources.

\subsection{A Preliminary Econometric Assessment}

Given that in most instances the adopted framework for deploying macroprudential instruments is a relatively recent phenomenon, it is challenging to provide a rigorous empirical assessment of their impact. There is limited data. However, we can ask, in a cross-country setting, whether certain proxies for variables that are likely to be affected by the loss of financial stability are related to the index developed in this paper. Ideally, we would like to perform a kind of treatment analysis, comparing economies with and without macroprudential frameworks. However, such an analysis is complicated by the fact that several of the economies not directly impacted by the financial crisis, at least in comparative terms, have also jumped on the bandwagon of creating a macroprudential framework. The work of the G20, the FSB, and the resulting demonstration effect elsewhere in the world have clearly played a role.

Accordingly, we perform a series of simple econometric tests. We estimate regressions of the following form:

$$
\Delta X_{\mathrm{i}}=\mathrm{a}_{0}+b_{0} C_{\mathrm{i}}+b_{1} \text { BCrisis }_{\mathrm{i}}+\varepsilon_{\mathrm{i}}
$$

where $\Delta X_{\mathrm{i}}=X_{\mathrm{i} 2}-X_{\mathrm{i} 1}$ is the change in a variable proxying financial stability over periods 1 and 2 (see below), and $i$ denotes the economy in question. $C$ represents the macroprudential capacity indicator developed in the paper for a particular economy $i$. We first estimate equation (1) using the unweighted normalized version of the index. The results are shown in Tables 3a and $3 \mathrm{~b}$. We also consider equation (1) under the six weighted versions of the index (incorporated in the range displayed in Figure 3). Then, using all seven normalized index values 
for each country, we collect the set of MAX, MIN, and MEDIAN values (also shown in Figure 3), and estimate equation (1) separately for each. ${ }^{19}$ This provides an idea of the sensitivity of our results to various assumptions about the capacity of an economy to deliver macroprudential policies.

Additionally, we include a control for the possibility that an economy's preparedness may well have been influenced according to whether they were directly affected by a banking crisis during the sample considered. The variable BCrisis takes on a value of 1 if a banking crisis is recorded otherwise the variable takes a value of zero. ${ }^{20}$

Next, we define the two periods to be considered as follows: period 1 is the mean of the variables considered below for the years 1999-2006 or 2002-2006, that is, the pre-crisis period. Period 2 then ranges from 2007-2013 to 2010-2014, defined either as the crisis sample or the Eurozone sovereign debt crisis period. ${ }^{21}$ Since the principal aim of macroprudential policies is the maintenance of financial system stability, we consider several candidate variables as a proxy for $X$. They are, not in order of importance, the variance of real GDP growth, the variance of inflation, an ex post measure of the real interest rate defined as the nominal short-term government bond yield less the average inflation rate in each period, different measures of credit growth, or the variance of credit growth. All of these variables have appeared in the literature as potential candidates that have systemic significance for financial stability.

Of all the proxies for $X$ considered, the only financial stability indicator that is consistently found to be statistically significant is the relationship between macroprudential capacity and

\footnotetext{
${ }^{19}$ For example, the US's highest normalized index value is achieved when scores are weighted by share of world GDP (this is also the case for the UK and Eurozone). Similarly, Brazil, Russia and South Africa achieve their highest normalized scores under the Shambaugh (2004) exchange rate regime indicator weighting scheme, and India and China score their highest normalized values when the index is unweighted. Equation (1) is then estimated separately using the set (denoted, 'MAX') of each economy's highest normalized value for $C$. The same is done using each economy's lowest values ('MIN') and median values, in addition to the simple unweighted index scores. ${ }^{20}$ Based on the dataset of Laeven and Valencia (2012). If an economy experienced a bank crisis in either of the two periods used in the regressions, the dummy was assigned a value of 1 (otherwise $=0$ ). The data are available from https://www.imf.org/external/pubs/ft/wp/2012/wp12163.pdf. We also estimated a version of equation (1) where capacity $(\mathrm{C})$ interacts with BCrisis. The results are essentially the same and are not discussed further.

${ }^{21}$ More precisely, six separate pairs of period 1 and period 2 definitions are used, with period 1 being any of 19992006, 1999-2007, 2002-2006, or 2002-2007; and period 2 being any of 2007-2013, 2008-2013, 2009-2014, or 20102014.
} 
credit growth. ${ }^{22}$ Hence, Tables $3 a$ and $3 b$ only show the results for the credit growth variable. The positive sign is consistent with the notion that a macroprudential regulatory framework with greater capacity is observed in economies where credit growth is rising. ${ }^{23}$ Also notable is that the banking crisis dummy is never statistically significant. ${ }^{24}$

Table $3 \mathrm{~b}$ presents the same regression results as in Table 3a. However, the version of the index used now favours the governance model where authority over monetary policy is centralized. The BCrisis dummy remains insignificant in all cases but the remaining results are not broadly different from the ones shown in Table 3a with one notable exception. There is now a significant response when considering economies' minimum index scores. Hence, even economies that do poorly on the macroprudential capacity scale show improvement in response to rising credit growth. In other words, macroprudential frameworks appear largely designed to deal with the financial stability challenges posed by credit.

\section{Conclusions and Policy Implications}

This paper takes stock of the state of play in 46 economies concerning the scope, preparedness, and governance of their macroprudential regimes. Using data collected from central banks, treasuries, regulatory authorities, the FSB, and the BIS, we have constructed an index of macroprudential capacity. The index represents an aggregation of eight categories consisting of over 30 characteristics that policy makers regard as desirable elements of a macroprudential regime.

Overall, we find that economies that were the most directly impacted by the global financial crisis are also the ones that have built up the greatest macroprudential capacity. Of course, since the global financial system has not been tested as it was during the global financial crisis,

\footnotetext{
${ }^{22}$ In Tables 3a and 3b only the case of domestic credit growth to the private sector by banks as a percent of GDP is shown. The same conclusions are obtained when total domestic credit growth to GDP is used. Slightly less conclusive results are obtained when the growth rates of the levels of various measures of domestic credit are used.

${ }^{23}$ All results not shown are available on request. We also considered an indicator of financial system stability or financial stress that several central banks have begun to publish. However, there were too few indicators available and the samples too brief to add to the list of proxies examined.

${ }^{24}$ These results also hold if we interact the crisis dummy with macroprudential capacity(not shown).
} 
we do not yet know for sure how resilient these frameworks actually are to a large financial shock. Nevertheless, the illustrative econometric results presented here do suggest that policies aimed at limiting credit growth have the best chance of being influenced by how the macroprudential framework is designed. This is the clearest policy implication from the construction of our index.

In a financially globalized environment, one element missing from our analysis is an indication of how closely policy makers, especially those in countries that belong to the $\mathrm{G} 20$, will be willing to cooperate in the event of another looming global financial crisis. The remarkable coming together of the major economies' policies in 2008 did much to prevent another Great Depression. However, while the policies to address the crisis produced a return to a form of financial system stability, they did not prevent significant economic costs to the global economy.

Still another important element absent from our analysis is some indication of how macroprudential policy makers plan to deal with the shadow banking system, which was an important contributor to the contagion that characterized the GFC. There is, at present, little evidence that a fully formed strategy exists for a segment of the financial system that has historically been a source of financial crises. Until policy makers are tested, or are able to develop tools that can get 'into all the cracks' of the financial system, existing macroprudential frameworks remain a 'work in progress.' Nevertheless, the sheer amount of effort devoted to dealing with the relevant questions should be viewed as a source of optimism.

Financial and economic systems are complex: highly interconnected, constantly in flux and prone to instability (e.g., Minsky 1992; Stiglitz 2010; the collection of works in Blume and Durlauf 2005). Identifying an effective macroprudential policy regime remains a daunting task given the current state of knowledge and the effectiveness of a macroprudential policy framework will depend on the specific context. Furthermore, the framework should adapt over time as information is acquired and experience is gained. Therefore, a macroprudential policy regime should not adopt a 'one-size-fits-all' approach. 


\section{REFERENCES}

Adrian, Tobias and Nellie Liang (2014). "Monetary Policy, Financial Conditions, and Financial Stability," Staff Reports 690, Federal Reserve Bank of New York.

Agénor, Pierre-Richard and Luiz A. Pereira da Silva (2014). "Inflation Targeting and Financial Stability: A Perspective from the Developing World," Working Paper Series 324, Central Bank of Brazil, Research Department.

Agur, Itai and Maria Demertzis (2012). "Excessive Bank Risk Taking and Monetary Policy," Working Paper Series 1457, European Central Bank.

Allen, William A. and Geoffrey Wood (2006). "Defining and Achieving Financial Stability," Journal of Financial Stability, vol. 2, issue 2, pp 152-72.

Anand, Anita I., Michael J. Trebilcock and Michael Rosenstock (2014). "Institutional Design and the New Systemic Risk in Banking Crises," May 14. Available at SSRN: http://ssrn.com/abstract=2437217.

Angelini, Paolo, Stefano Neri, and Fabio Panetta (2014), "The Interaction between Capital Requirements and Monetary Policy," Journal of Money, Credit and Banking 46(6), pp. 10731112.

Bank for International Settlements (2014), Annual Report (Basel: Switzerland), available from www.bis.org.

Bank of England (2015). “One Bank Research Agenda," discussion paper, February.

Bank of England (2009). "The Role of Macroprudential Policy: A Discussion Paper," available at www.bankofengland.co.uk/publications/Documents/other/financialstability/roleofmacroprude ntialpolicy091121.pdf.

Barwell, Richard (2013). Macroprudential Policy (Houndmills, Basingstoke: Palgrave Macmillan).

Bini Smaghi, Lorenzo (2009). "Macro-prudential Supervision," Speech at the CEPR/ESI 13th Annual Conference on "Financial Supervision in an Uncertain World", European Banking Center at Venice International University, Venice, 25-26 September.

Borio, Claudio and Mathias Drehmann (2009). "Towards an Operational Framework for Financial Stability: 'Fuzzy' Measurement and its Consequences," Central Banking, Analysis, and 
Economics Policies Book Series, in: Rodrigo Alfaro (ed.), Financial Stability, Monetary Policy, and Central Banking, edition 1, volume 15, chapter 4, pages 063-123 Central Bank of Chile.

Borio, Claudio and William White (2004). "Whither Monetary and Financial Stability? The Implications of Evolving Policy Regimes," Proceedings - Economic Policy Symposium - Jackson Hole, Federal Reserve Bank of Kansas City, pages 131-211.

Brainard, William (1967). "Uncertainty and the Effectiveness of Policy," American Economic Review 57: 411-425.

Cerutti, E., S. Claessens and L. Laeven (2015). "The Use and Effectiveness of Macroprudential Policies: New Evidence," IMF working paper 15/61, March.

Chinn, Menzie and Hiro Ito (2006). "What Matters for Financial Development? Capital Controls, Institutions, and Interactions," Journal of Development Economics 81 (October): 163-192.

Claessens, S. (2014). "An Overview of Macroprudential Policy Tools," IMF working paper $14 / 2014$.

Crockett, Andrew (2000). "Marrying the Micro- and Macro-prudential Dimensions of Financial Stability," speech before the $11^{\text {th }}$ International Conference on Banking Supervision, Basel, September 20-21.

De Paoli, Bianca and Matthias Paustian (2013). "Coordinating Monetary and Macroprudential Policies," Staff Reports 653, Federal Reserve Bank of New York.

Dell'Ariccia, Giovanni, Deniz Igan, Luc Laeven and Hui Tong (2012). "Policies for Macrofinancial Stability: How to Deal with Credit Booms," IMF Staff Discussion Note No. 12/06, International Monetary Fund, Washington DC.

Dincer, N. Nergiz and Barry Eichengreen (2014). "Central Bank Transparency and Independence: Updates and New Measures," International Journal of Central Banking (March): 189-253.

Eichengreen, Barry et al. (2011). "Rethinking Central Banking," Brookings Committee on International Economic Policy and Reform.

Fernández, Andrés, Michael W. Klein, Alessandro Rebucci, Martin Schindler and Martin Uriber (2015), “Capital Control Measures: A New Data Set," IMF working paper 15/80, April.

Freixas, Xavier, Luc Laeven, and J.-L. Peydró (2015). Systemic Risk, Crises, and Macroprudential Regulation (Cambridge, Mass.: The MIT Press). 
Galati, Gabriele and Richhild Moessner (2014). "What Do We Know About the Effects of Macroprudential Policy?" DNB working paper 440, Netherlands Central Bank.

Galati, Gabriele and Richhild Moessner (2011). "Macroprudential Policy - A Literature Review," Journal of Economic Surveys, Wiley Blackwell, vol. 27(5), pages 846-878, December.

Ghilardi, Matteo F.and Shanaka J. Peiris (2016), "Capital Flows, Financial Intermediation and Macroprudential Policies," Open Economies Review, 27(September), pp. 721-746.

Goodfriend, Marvin (2012). "The Elusive Promise of Independent Central Banking," Bank of Japan Monetary and Economic Studies, vol. 30, pp. 39-54.

Goodhart, Charles (2014). "The Use of Macroprudential Instruments," Schoenmaker, D. (Ed.) Macroprudentialism (pp. 11-17). London, UK: Centre for Economic Policy Research.

Goodhart, Charles and Dirk Schoenmaker (1995). "Should the Functions of Monetary Policy and Banking Supervision be Separated?" Oxford Economic Papers, Oxford University Press, vol. 47(4), pages 539-60, October.

Houben, Aerdt, Jan Kakes and Garry Schinasi (2004). "Towards a Framework for Financial Stability," DNB Occasional Studies 201, Netherlands Central Bank, Research Department.

IMF (2011). "Macroprudential Policy: An Organizing Framework," Washington: International Monetary Fund.

IMF (2013a). "The Interaction of Monetary and Macroprudential Policies - Background Paper," Washington: International Monetary Fund.

IMF (2013b). "Key Aspects of Macroprudential Policy," Washington: International Monetary Fund.

Ingves, Stefan (2011). Central Bank Governance and Financial Stability A Report by a Study Group. Basel, Switzerland, Bank for International Settlements. http://www.bis.org/publ/othp14.pdf.

Knot, Klaas (2014). "Governance of Macroprudential Policy," Banque de France Financial Stability Review, No. 18: 25-32.

Kohn, Donald (2009). "Policy Challenges for the Federal Reserve," Speech at the Kellogg Distinguished Lecture Series, Kellogg School of Management, Northwestern University, Evanston, Illinois, 16 November. 
Kuttner, Kenneth N., and Ilhyock Shim (2013). "Can Non-interest Rate Policies Stabilize Housing Markets? Evidence from a Panel of 57 Economies," NBER Working Papers19723, National Bureau of Economic Research, Inc.

Laeven, Luc and Fabián Valencia (2012). "Systemic Banking Crises Database: An Update," IMF Working Paper no. 12/163.

Leduc, Sylvain, and J.-M. Natal (2015). "Monetary and Macroprudential Policy in a Leveraged Economy," Federal Reserve Bank of San Francisco working paper 2015-11, April.

Lim, Cheng Hoon, Rishi Ramchand, Hong Wang and Xiaoyong Wi (2013a). "Institutional Arrangements for Macroprudential Policy in Asia," IMF Working Papers 13/165, International Monetary Fund.

Lim, Cheng Hoon, Ivo Krznar, Fabian Lipinsky, Akira Otani and Xiaoyong Wu (2013b). "The Macroprudential Framework; Policy Responsiveness, and Institutional Arrangements," IMF Working Papers 13/166, International Monetary Fund.

Masciandaro, Donato and Alessio Volpicella (2016), "Macroprudential Governance and Central Banks: Facts and Drivers", Journal of International Money and Finance 61, pp. 101-119.

McDonald, Chris (2015). "When Is Macroprudential Policy Effective?" BIS working paper No. 496, March.

Minsky, Hyman P. (1992). "The Financial Instability Hypothesis," Levy Economics Institute Working Paper No. 74, May.

Padoa-Schioppa, Tommaso (2003). "The Transformation of the European Financial System," Policy Panel Introductory Paper, European Central Bank.

Pan, Eric J. (2010). "Challenge of International Cooperation and Institutional Design in Financial Supervision: Beyond Transgovernmental Networks," April 20. Available at SSRN: http://ssrn.com/abstract=1593334.

Portes, Richard (2014). "Macroprudential Policy and Monetary Policy," in D. Schoenmaker (Ed.), Macroprudentialism (London: CEPR Press).

Schoenmaker, Dirk (2014). "Introduction" Schoenmaker, D. (Ed.) Macroprudentialism (pp. 1-8). London, UK: Centre for Economic Policy Research.

Shambaugh, Jay C. (2004). "The Effect of Fixed Exchange Rates on Monetary Policy," Quarterly Journal of Economics 119 (February): 301-352. 
Shirakawa, Masakki (2009). "International Policy Response to Financial Crises," Speech at the Federal Reserve Bank of Kansas City's Annual Economic Symposium, Jackson Hole, Wyoming, 21 August.

Stiglitz, Joseph E. (2010). "Risk and Global Economic Architecture: Why Full Financial Integration may be Undesirable," American Economic Review 100(2), 388-92.

Taylor, J.B. (1993). "Discretion Versus Policy Rules in Practice," Carnegie-Rochester Conference Series on Public Policy, Elsevier, vol. 39(1), pages 195-214, December.

Tucker, Paul (2014a). "The Political Economy of Macroprudential Regimes," Schoenmaker, D. (Ed.) Macroprudentialism (pp. 61-72). London, UK: Centre for Economic Policy Research.

Tucker, Paul (2014b). "The Only Game in Town? A New Constitution for Money (and Credit) Policy," Myron Scholes Lecture, University of Chicago, 22 May.

Warsh, Kevin (2014). "Rethinking Macro: Reassessing Micro-foundations," in M.N. Bailey and J. B. Taylor (Eds.), Across the Great Divide: New Perspectives on the Financial Crisis (Stanford, Ca.: Hoover Institution Press), pp. 67-88.

Whelan, K. (2012). "Should Monetary Policy Be Separated From Banking Superivsion?," Note for the DIRECTORATE GENERAL FOR INTERNAL POLICIES POLICY DEPARTMENT A: ECONOMIC AND SCIENTIFIC POLICY, IP/A/ECON/NT/2012-06, December, Part of the compilation PE 492.456 for the Monetary Dialogue.

Yueh, Linda (2015). "The Bank of England's Theory of Everything," BBC News, 15 February.

Zhang, L., and E. Zoli (2014). "Leaning against the wind: Macroprudential policy in Asia," IMF working paper 14/22. 

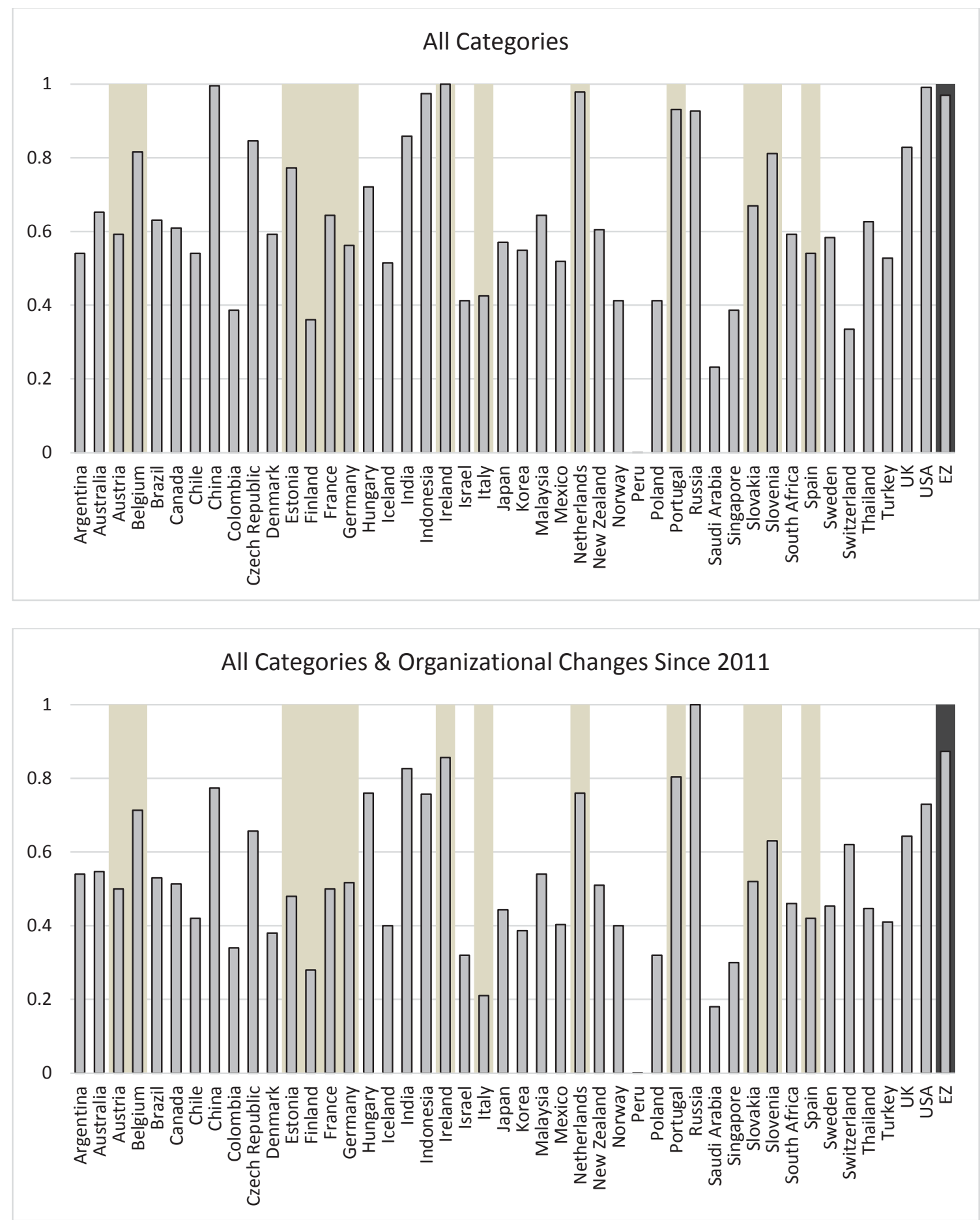

Note: Top figure is based on the aggregation of the 8 categories listed in Table 1a. The bottom figure adds an indicator of the organizational changes in central banks since 2011 to the aggregate index shown in the top portion of the FigureThe data have been normalized to range between 0 and 1 . The shaded areas identify countries that belong to the Eurozone. The version of the index shown here favours decentralized authority over macroprudential policies. 
Figure 2 - Benchmarking Macroprudential Policies: Select Categories, Normalized

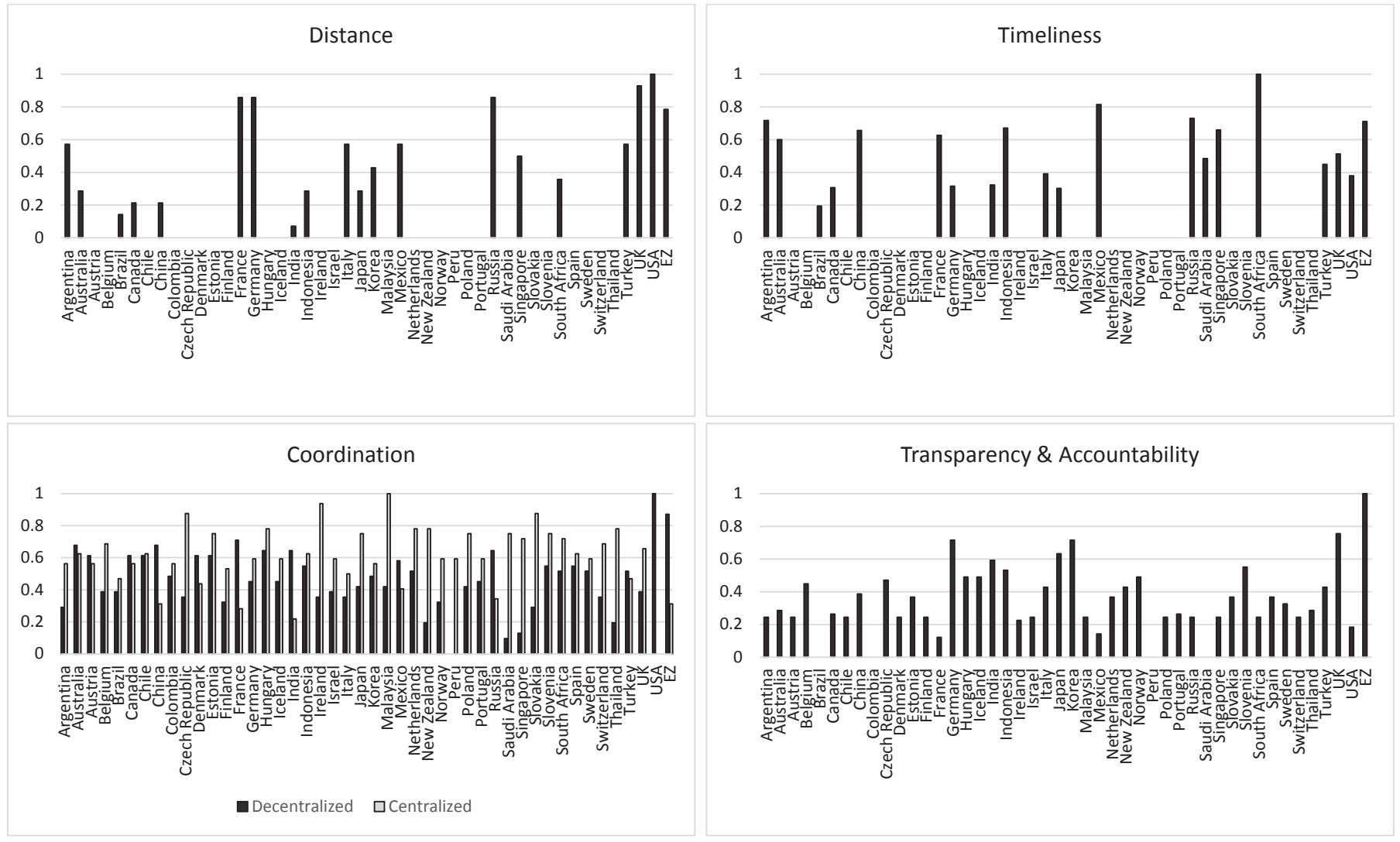

Note: Distance and timeliness only for FSB member economies. Also, see Table 1a and Figure 1. The index is normalized to range from 0 to 1 . Decentralized refers to the assumption that capacity is improved when the central bank is not the only insititution responsible for macroprudential policies; Centralized biases the index in favour of a single authority (i.e., the central bank). See Table $1 \mathrm{~b}$ for details. Note that no values are assigned to distance and timelines in non-FSB member economies. 
Figure 3a - Benchmarking Macroprudential Policies: Range of Normalized Index Values

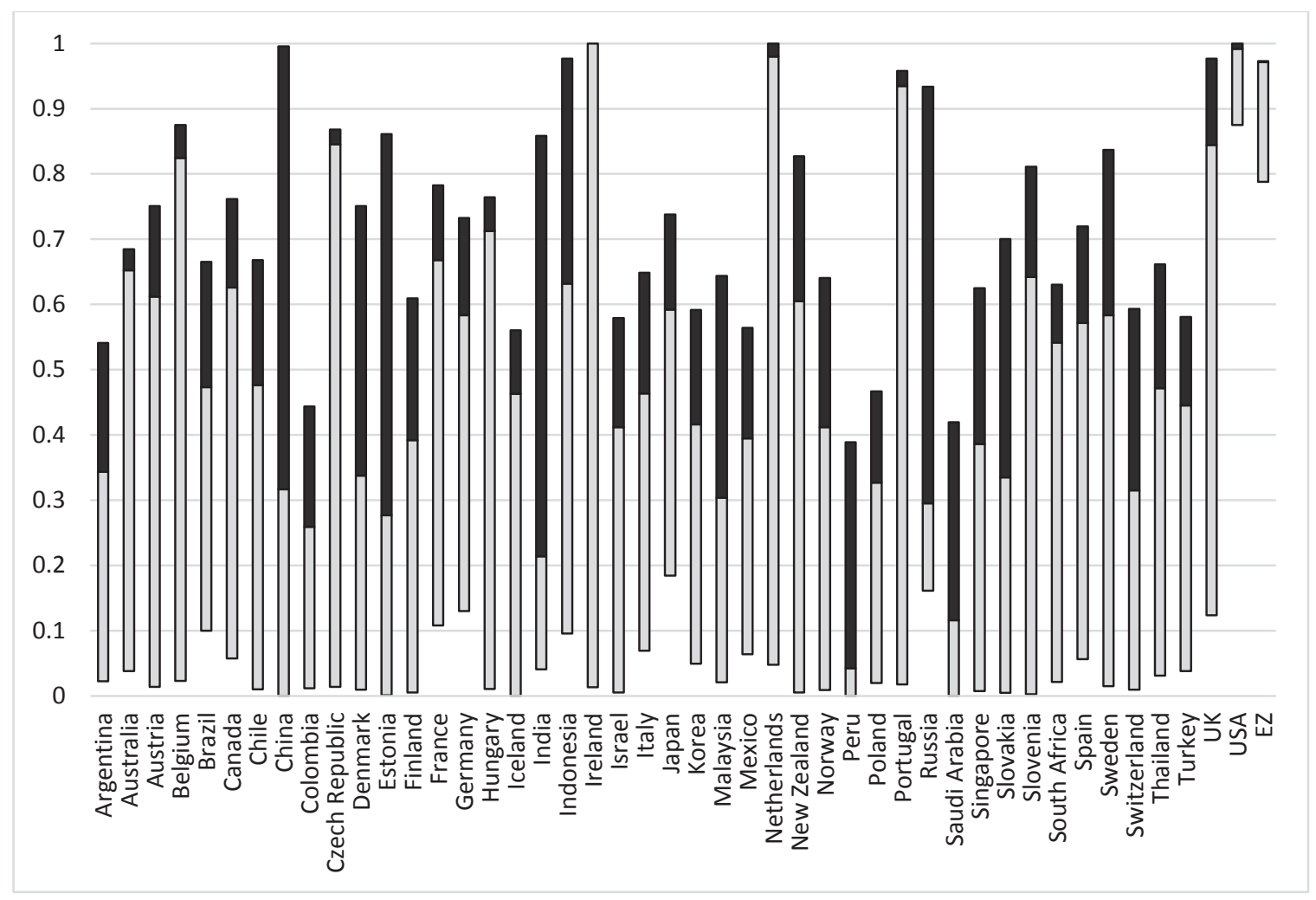

Note: based on the max (most capacity), min (least capacity), and median of seven different versions of the macroprudential indicator index. They are: unweighted, share of world GDP, Reinhart and Rogoff (2004) exchange rate regime index (coarse), Shambaugh (2004) exchange rate regime indicator, central bank transparency index (Dincer and Eichengreen 2014), capital account openness (Chinn and Ito 2006), and capital controls indicator (Fernandez et al. 2015). The version of the index shown here favours decentralized authority over macroprudential policies. 


\section{Table 1a - Macroprudential Capacity Indicator: Categories}

\begin{tabular}{|c|c|c|c|c|}
\hline Section & Feature & Description & $\begin{array}{l}\text { Sign of the } \\
\text { contribution } \\
\text { to the indicator }\end{array}$ & Weight \\
\hline 1 & $\begin{array}{l}\text { Implementing Macroprudential Policy: } \\
\text { The Constituents of Financial System } \\
\text { Stability }\end{array}$ & $\begin{array}{l}\text { Includes information about central bank's authority to implement } \\
\text { macroprudential instruments, availability of instruments to the central bank, } \\
\text { flexibility to implement macroprudential type policies. }\end{array}$ & + & 0.20 \\
\hline 2 & $\begin{array}{l}\text { Coordination of Relevant Entities \& } \\
\text { Responsibility for Macroprudential } \\
\text { Policy: Central Bank vs. Relevant } \\
\text { Entities }\end{array}$ & $\begin{array}{l}\text { Specifics regarding coordinating body and entities sharing the financial stability } \\
\text { mandate. Includes number of members, chair, and central banks involvement. } \\
\text { Also includes central bank's 'recognition' of financial stability, i.e. explicit } \\
\text { definition and/or inclusion of mandate in legislation (or elsewhere). }\end{array}$ & + & 0.25 \\
\hline 3 & Deposit Insurance & Deposit insurance details (if applicable), savings limit, \% coverage, etc. & + & 0.05 \\
\hline 4 & $\begin{array}{l}\text { Transparency \& Accountability: } \\
\text { Speeches, Media Releases, Financial } \\
\text { Stability Reports }\end{array}$ & $\begin{array}{l}\text { Captures relevance of macroprudential regulation and financial stability as } \\
\text { measured through speeches with topics as a main focus. Also includes financial } \\
\text { stability report details, including size of macroprudential 'section' if applicable. }\end{array}$ & + & 0.10 \\
\hline 5 & $\begin{array}{l}\text { Governance of Macroprudential } \\
\text { Policies }\end{array}$ & $\begin{array}{l}\text { Size of the Policy making Committee and number of layers (departments/levels in } \\
\text { the Central Bank and place of financial stability in the organization) }\end{array}$ & + & 0.10 \\
\hline 6 & $\begin{array}{l}\text { The Place of Macroprudential Policy in } \\
\text { the Monetary Policy Transmission } \\
\text { Mechanism }\end{array}$ & $\begin{array}{l}\text { Captures any publicly recognized (by central bank) relationship between } \\
\text { monetary policy and macroprudential regulation. Includes (if applicable) } \\
\text { relationship with financial stability, inflation, real economic growth. }\end{array}$ & + & 0.05 \\
\hline 7 & $\begin{array}{l}\text { Distance to FSB/G20 } \\
\text { Recommendations }\end{array}$ & $\begin{array}{l}\text { Taken from } 2013 \text { surveys of national progress. Measures 'improvements' in } \\
\text { macroprudential regulation as per survey questions. Specifically regarding } \\
\text { regulatory framework, monitoring, and supervisor/central bank cooperation }\end{array}$ & + & 0.15 \\
\hline 8 & $\begin{array}{l}\text { Response Time to FSB } \\
\text { Recommendations }\end{array}$ & $\begin{array}{l}\text { Overall estimate of response time to recommendations (taken from surveys of } \\
\text { national progress) }\end{array}$ & - & 0.10 \\
\hline
\end{tabular}

Sources: See Appendix. FSB is the Financial Stability Board; G20 is the Group of 20 economies.

Notes (refer to section numbers above): 1. A higher value indicates greater capacity due to the availability of more instruments, greater autonomy for the central bank to implement macroprudential policy, and more formality in the assignment of responsibility for macroprudential policy; 2. Using the FSB/G20 benchmarks, a higher value implies a smaller distance to the stated objectives; 3 . Based on 11 different areas of financial stability, and using 2008 as the benchmark year (the year the Global Financial Crisis erupted) we subtracted 2008 from the year of completion of a reform (if available) and then average over all the areas identified by the FSB/G20; 4 . The higher the value the greater the capacity since this indicates that areas of responsibility are clearer and more formally assigned; 5 . Presence of deposit insurance indicates greater resilience as well as time for policy makers to respond to large financial shocks; 6 . Recognition that there is interconnectedness between monetary policy and financial stability is seen as an indication of greater central bank capacity to deal with macroprudential questions; 7. Greater transparency and accountability is viewed as conducive and evidence of greater central bank capacity in macroprudential policy; 8. Expansion in organizational capacity, measured by the size of the committee(s) dealing with both monetary policy and financial stability issues and the addition of levels of authority in the central bank is viewed as an indication of greater capacity. 


\section{Table 1b - Macroprudential Capacity Indicator: Coding}

\begin{tabular}{|c|c|c|c|c|}
\hline Categories & & YES & NO & Other \\
\hline \multirow{4}{*}{$\begin{array}{l}\text { Implementing MaP } \\
\text { Policy }\end{array}$} & Number of macroprudential instruments possessed and declared by the CB & & & \# \\
\hline & Is the CB free to implement available macroprudential instruments ? & 1 & 0 & \\
\hline & Is there government involvement in MaP instrument - related decisions? & 0 & 1 & \\
\hline & $\begin{array}{l}\text { Macroprudential Implementation specified in primary, secondary legislation, or } \\
\text { regulation? }\end{array}$ & & & Pri $=1$, Sec $=.5$, Regu $=.25$, Oth $=0$ \\
\hline \multirow{3}{*}{$\begin{array}{l}\text { Distance to FSB/G20 } \\
\text { Map Recomm. }\end{array}$} & Regulatory Framework for macroprudential Oversight & & & Pri $=1$, Sec $=.5$, Regu=.25, Oth $=0$ \\
\hline & System-wide monitoring and the use of macrprudential instruments & & & Pri $=1$, Sec $=.5$, Regu= .25 , Oth $=0$ \\
\hline & Improved cooperation between supervisors and central banks & & & Pri $=1$, Sec $=.5$, Regu= .25, Oth $=0$ \\
\hline $\begin{array}{l}\text { Response Time to } \\
\text { FSB Recomm. }\end{array}$ & Distance from FSB recommendations & & & Timeliness (years) \\
\hline \multirow{16}{*}{$\begin{array}{l}\text { Coordination of } \\
\text { Relevant Entities \& } \\
\text { Responsibility for } \\
\text { Map Policy }\end{array}$} & Is CB the explicitly mentioned macroprudential authority? & 1 & 0 & \\
\hline & Is macroprudential explicitly in CB legislation? & 1 & 0 & \\
\hline & Is there a financial stability/macroprudential coordinating body? & 1 & 0 & \\
\hline & \# (voting) members & & & \# \\
\hline & ... \# non-voting members & \multicolumn{2}{|c|}{ NS = Not specified } & $\# / 2$ \\
\hline & Is the CB a member? & 1 & 0 & \\
\hline & Does CB chair coordination body? & 1 & 0 & \\
\hline & If no body - Does CB share financial stability/macroprudential mandate? & 1 & 0 & \\
\hline & If no body - Is CB sole owner of the mandate? & 0 & 1 & \\
\hline & If no body - is there implicit coordination through MoUs? & 0.5 & 0 & \\
\hline & if no body - ...how many in total share? (incl. cb) & & & $\# / 2$ \\
\hline & Is Fin Stab explicitly the responsibility of the CB? & 1 & 0 & \\
\hline & ...explicit in CB legislation? & 1 & 0 & Indirect cases: 0.5 \\
\hline & Does the CB have an explicit definition of Financial Stability? & 1 & 0 & \\
\hline & YES? In the legislation? & 1 & 0 & \\
\hline & Elsewhere? & 0.5 & 0 & \\
\hline Deposit Insurance & Is there Deposit Insurance? & 1 & 0 & \\
\hline $\begin{array}{l}\text { The Place of Map } \\
\text { Policy in the } \\
\text { Monetary Policy } \\
\text { Transmission } \\
\text { Mechanism }\end{array}$ & $\begin{array}{l}\text { Does the CB draw a link/links between Monetary Policy and Macroprudential } \\
\text { Policy? }\end{array}$ & 1 & 0 & \\
\hline \multirow{6}{*}{$\begin{array}{l}\text { Transparency and } \\
\text { Accountability }\end{array}$} & Going back to 2008 , \# of Speeches with 'Macroprudential' in Title & & & $\# / 12$ \\
\hline & Going back to 2008 , \# of Press Releases with 'Macroprudential' in Title & & & \#/ 12 \\
\hline & Does the Central Bank publish a separate Financial Stability Report? & 1 & 0 & \\
\hline & ...is there a section explicity devoted to macroprudential policy? & 0.5 & 0 & \\
\hline & $\begin{array}{l}\text { Does an authority other than the Central Bank publish a separate Financial } \\
\text { Stability Report? }\end{array}$ & 0.5 & 0 & \\
\hline & ...is there a section explicity devoted to macroprudential policy? & 0.25 & 0 & \\
\hline \multirow{8}{*}{$\begin{array}{l}\text { Organization } \\
\text { Structure: Changes } \\
\text { Since the Crisis }\end{array}$} & Number of Monetary Policy Committee Members (if applicable) & & & \# \\
\hline & Number of Financial Stability Committee Members (if applicable) & & & \# \\
\hline & Is there a separate Financial Stability Committee? & 1 & 0 & \\
\hline & $\begin{array}{l}\text { Change in \#"major" depts based on the available organizational charts since } \\
\text { 2001* }\end{array}$ & & & \# \\
\hline & $\begin{array}{l}\text { Change in \#"major" depts based on the available organizational charts since } \\
2011^{* *}\end{array}$ & & & $\#$ \\
\hline & Is there a distinct financial stability department? & 1 & 0 & \\
\hline & $\begin{array}{l}\text { If so, is it on the same 'level' as department responsible for macroprudential } \\
\text { policy? }\end{array}$ & 1 & 0 & \\
\hline & Does it report to the same deputy governor? & 1 & 0 & \\
\hline
\end{tabular}

Notes: The values are assigned depending on whether or not (YES or NO) the element in question is present. \# refers to the number of instruments, committees, institutions, and organizational changes that were recorded. Data were collected from the BIS, the FSB, national central banks, and the IMF. Pri.= primary, Sec.= secondary, Regu.=Regulation, and Oth.=other, refers to how macroprudential rules and regulations are defined and their location (legislation versus other). Indirect cases refers to a reference to financial stability concerns that is not explicit but is mentioned indirectly. $\mathrm{CB}=$ central bank, $\mathrm{MaP}=$ macroprudential. Data sources are listed in the text. Also, see Table 1a. 
Table 2a. Macroprudential Raw Index Values Under Different Scenarios

\begin{tabular}{|c|c|c|c|c|c|}
\hline \multirow[b]{2}{*}{ Economy } & \multicolumn{2}{|c|}{$\mathrm{MaP}$} & \multicolumn{3}{|c|}{ MaP (FSB members only) } \\
\hline & $\begin{array}{c}\text { All (No } \\
\text { department } \\
\text { details) }\end{array}$ & $\begin{array}{c}\text { All (2011 } \\
\text { department } \\
\text { changes) }\end{array}$ & $\begin{array}{c}\text { All (No } \\
\text { department } \\
\text { details) }\end{array}$ & $\begin{array}{c}\text { All (2011 } \\
\text { department } \\
\text { changes) }\end{array}$ & $\begin{array}{l}\text { All (No department } \\
\text { details), Weighted }\end{array}$ \\
\hline Argentina & 12.50 & 15.50 & 9.61 & 12.61 & 2.34 \\
\hline Australia & 14.67 & 15.67 & 11.29 & 12.29 & 2.95 \\
\hline Austria & 13.50 & 14.50 & NA & NA & NA \\
\hline Belgium & 17.83 & 19.83 & NA & NA & NA \\
\hline Brazil & 14.25 & 15.25 & 12.14 & 13.14 & 2.66 \\
\hline Canada & 13.83 & 14.83 & 11.48 & 12.48 & 2.69 \\
\hline Chile & 12.50 & 12.50 & NA & NA & NA \\
\hline China & 21.33 & 21.33 & 17.45 & 17.45 & 4.03 \\
\hline Colombia & 9.50 & 10.50 & NA & NA & NA \\
\hline Czech Rep. & 18.42 & 18.42 & NA & NA & NA \\
\hline Denmark & 13.50 & 11.50 & NA & NA & NA \\
\hline Estonia & 17.00 & 14.00 & NA & NA & NA \\
\hline Finland & 9.00 & 9.00 & NA & NA & NA \\
\hline France & 14.50 & 14.50 & 13.00 & 13.00 & 3.30 \\
\hline Germany & 12.92 & 14.92 & 12.77 & 14.77 & 2.68 \\
\hline Hungary & 16.00 & 21.00 & $\mathrm{NA}$ & NA & NA \\
\hline Iceland & 12.00 & 12.00 & NA & NA & NA \\
\hline India & 18.67 & 22.67 & 15.75 & 19.75 & 3.61 \\
\hline Indonesia & 20.92 & 20.92 & 17.23 & 17.23 & 3.82 \\
\hline Ireland & 21.42 & 23.42 & NA & NA & NA \\
\hline Israel & 10.00 & 10.00 & NA & NA & NA \\
\hline Italy & 10.25 & 7.25 & 8.78 & 5.78 & 2.00 \\
\hline Japan & 13.08 & 13.08 & 11.01 & 11.01 & 2.28 \\
\hline Korea & 12.67 & 11.67 & 12.40 & 11.40 & 2.57 \\
\hline Malaysia & 14.50 & 15.50 & NA & NA & NA \\
\hline Mexico & 12.08 & 12.08 & 8.77 & 8.77 & 2.48 \\
\hline Netherlands & 21.00 & 21.00 & NA & NA & NA \\
\hline New Zealand & 13.75 & 14.75 & NA & NA & NA \\
\hline Norway & 10.00 & 12.00 & NA & NA & NA \\
\hline Peru & 2.00 & 2.00 & NA & NA & NA \\
\hline Poland & 10.00 & 10.00 & NA & NA & NA \\
\hline Portugal & 20.08 & 22.08 & NA & NA & NA \\
\hline Russia & 20.00 & 27.00 & 18.05 & 25.05 & 4.26 \\
\hline Saudi Arabia & 6.50 & 6.50 & 2.62 & 2.62 & 1.04 \\
\hline Singapore & 9.50 & 9.50 & 6.61 & 6.61 & 1.40 \\
\hline Slovakia & 15.00 & 15.00 & NA & NA & NA \\
\hline Slovenia & 17.75 & 17.75 & NA & NA & NA \\
\hline South Africa & 13.50 & 13.50 & 8.62 & 8.62 & 2.27 \\
\hline Spain & 12.50 & 12.50 & NA & NA & NA \\
\hline Sweden & 13.33 & 13.33 & NA & NA & NA \\
\hline Switzerland & 8.50 & 17.50 & NA & NA & NA \\
\hline Thailand & 14.17 & 13.17 & NA & NA & NA \\
\hline Turkey & 12.25 & 12.25 & 10.53 & 10.53 & 2.50 \\
\hline UK & 18.08 & 18.08 & 17.33 & 17.33 & 3.25 \\
\hline USA & 21.25 & 20.25 & 21.33 & 20.33 & 4.68 \\
\hline EZ & 20.83 & 23.83 & 18.71 & 21.71 & 4.11 \\
\hline
\end{tabular}

Note: MaP (macroprudential) index. The correlation between the weighted and unweighted index is 0.97 . Department changes refer to the Organizational Structure of the MaP framework. See Table $1 \mathrm{~b}$. 
Table 2b. Individual Categories of the Index: Raw Index Values

\begin{tabular}{|c|c|c|c|c|c|c|c|c|c|}
\hline & $\begin{array}{l}\text { Cat. 1: } \\
\text { Implemen } \\
\text { ting } \\
\text { Macropru } \\
\text { dential } \\
\text { Policy }\end{array}$ & $\begin{array}{c}\text { Cat. 2: } \\
\text { Coordination } \\
\& \\
\text { Responsibility }\end{array}$ & $\begin{array}{c}\text { Cat. 3: } \\
\text { Deposit } \\
\text { Insurance }\end{array}$ & $\begin{array}{c}\text { Cat. 4: } \\
\text { Transpare } \\
\text { ncy \& } \\
\text { Accounta } \\
\text { bility }\end{array}$ & \multicolumn{2}{|c|}{$\begin{array}{l}\text { Cat. 5: Governance } \\
(2001 / 2011)\end{array}$} & $\begin{array}{c}\text { Cat. 6: } \\
\text { Macroprudentia } \\
\text { I Policy in the } \\
\text { Monetary Policy } \\
\text { Transmission } \\
\text { Mechanism }\end{array}$ & $\begin{array}{c}\text { Cat. 7: } \\
\text { Distance to } \\
\text { FSB/G20 } \\
\text { Macroprude } \\
\text { ntial } \\
\text { Recommen } \\
\text { dations }\end{array}$ & $\begin{array}{c}\text { Cat. 8: } \\
\text { Response } \\
\text { Time }\end{array}$ \\
\hline Argentina & 5.00 & 5.50 & 1.00 & 1.00 & 3.00 & 3.00 & 0.00 & 2.00 & 4.89 \\
\hline Australia & 1.00 & 11.50 & 1.00 & 1.17 & 3.00 & 3.00 & 0.00 & 1.00 & 4.38 \\
\hline Austria & 1.00 & 10.50 & 1.00 & 1.00 & 2.00 & 2.00 & 0.00 & 0.00 & NA \\
\hline Belgium & 7.00 & 7.00 & 1.00 & 1.83 & 4.00 & 3.00 & 1.00 & 0.00 & NA \\
\hline Brazil & 5.25 & 7.00 & 1.00 & 0.00 & 16.00 & 4.00 & 0.00 & 0.50 & 2.61 \\
\hline Canada & 0.25 & 10.50 & 1.00 & 1.08 & 4.00 & 3.00 & 1.00 & 0.75 & 3.10 \\
\hline Chile & 0.00 & 10.50 & 1.00 & 1.00 & -4.00 & 2.00 & 0.00 & 0.00 & NA \\
\hline China & 6.25 & 11.50 & 1.00 & 1.58 & 2.00 & 2.00 & 1.00 & 0.75 & 4.63 \\
\hline Colombia & 0.00 & 8.50 & 1.00 & 0.00 & 2.00 & 2.00 & 0.00 & 0.00 & NA \\
\hline $\begin{array}{l}\text { Czech } \\
\text { Republic }\end{array}$ & 8.00 & 6.50 & 1.00 & 1.92 & 3.00 & 2.00 & 1.00 & 0.00 & NA \\
\hline Denmark & 1.00 & 10.50 & 1.00 & 1.00 & -4.00 & 0.00 & 0.00 & 0.00 & NA \\
\hline Estonia & 4.00 & 10.50 & 1.00 & 1.50 & -10.00 & -2.00 & 0.00 & 0.00 & NA \\
\hline Finland & 1.00 & 6.00 & 1.00 & 1.00 & 9.00 & 2.00 & 0.00 & 0.00 & NA \\
\hline France & 1.00 & 12.00 & 1.00 & 0.50 & 3.00 & 2.00 & 0.00 & 3.00 & 4.50 \\
\hline Germany & 1.00 & 8.00 & 1.00 & 2.92 & 7.00 & 5.00 & 0.00 & 3.00 & 3.14 \\
\hline Hungary & 1.00 & 11.00 & 1.00 & 2.00 & 13.00 & 8.00 & 1.00 & 0.00 & NA \\
\hline Iceland & 0.00 & 8.00 & 1.00 & 2.00 & 2.00 & 2.00 & 1.00 & 0.00 & NA \\
\hline India & 4.25 & 11.00 & 1.00 & 2.42 & 14.00 & 6.00 & 0.00 & 0.25 & 3.17 \\
\hline Indonesia & 7.25 & 9.50 & 1.00 & 2.17 & 2.00 & 2.00 & 1.00 & 1.00 & 4.69 \\
\hline Ireland & 11.00 & 6.50 & 1.00 & 0.92 & 2.00 & 6.00 & 1.00 & 0.00 & NA \\
\hline Israel & 0.00 & 7.00 & 1.00 & 1.00 & -5.00 & 0.00 & 1.00 & 0.00 & NA \\
\hline Italy & 1.00 & 6.50 & 1.00 & 1.75 & -3.00 & 0.00 & 0.00 & 2.00 & 3.47 \\
\hline Japan & 1.00 & 7.50 & 1.00 & 2.58 & 1.00 & 2.00 & 1.00 & 1.00 & 3.08 \\
\hline Korea & 0.25 & 8.50 & 1.00 & 2.92 & -1.00 & -1.00 & 0.00 & 1.50 & 1.76 \\
\hline Malaysia & 5.00 & 7.50 & 1.00 & 1.00 & 6.00 & 3.00 & 0.00 & 0.00 & NA \\
\hline Mexico & 0.50 & 10.00 & 1.00 & 0.58 & 7.00 & 2.00 & 0.00 & 2.00 & 5.32 \\
\hline Netherlands & 9.50 & 9.00 & 1.00 & 1.50 & 4.00 & 2.00 & 0.00 & 0.00 & NA \\
\hline $\begin{array}{l}\text { New } \\
\text { Zealand }\end{array}$ & 7.00 & 4.00 & 0.00 & 1.75 & 3.00 & 3.00 & 1.00 & 0.00 & NA \\
\hline Norway & 1.00 & 6.00 & 1.00 & 2.00 & 11.00 & 5.00 & 0.00 & 0.00 & NA \\
\hline Peru & 0.00 & 1.00 & 1.00 & 0.00 & 3.00 & 3.00 & 0.00 & 0.00 & NA \\
\hline Poland & 0.50 & 7.50 & 1.00 & 1.00 & 6.00 & 1.00 & 0.00 & 0.00 & NA \\
\hline Portugal & 10.00 & 8.00 & 1.00 & 1.08 & 8.00 & 4.00 & 0.00 & 0.00 & NA \\
\hline Russia & 7.00 & 11.00 & 1.00 & 1.00 & 18.00 & 10.00 & 0.00 & 3.00 & 4.95 \\
\hline $\begin{array}{l}\text { Saudi } \\
\text { Arabia }\end{array}$ & 4.00 & 2.50 & 0.00 & 0.00 & 3.00 & 3.00 & 0.00 & 0.00 & 3.88 \\
\hline Singapore & 3.50 & 3.00 & 1.00 & 1.00 & 2.00 & 2.00 & 0.00 & 1.75 & 4.64 \\
\hline Slovakia & 7.00 & 5.50 & 1.00 & 1.50 & -3.00 & 2.00 & 0.00 & 0.00 & NA \\
\hline Slovenia & 5.00 & 9.50 & 1.00 & 2.25 & 0.00 & 1.00 & 0.00 & 0.00 & NA \\
\hline South Africa & 1.50 & 9.00 & 1.00 & 1.00 & 1.00 & 1.00 & 0.00 & 1.25 & 6.13 \\
\hline Spain & 0.50 & 9.50 & 1.00 & 1.50 & 1.00 & 2.00 & 0.00 & 0.00 & NA \\
\hline Sweden & 1.00 & 9.00 & 1.00 & 1.33 & -4.00 & 2.00 & 1.00 & 0.00 & NA \\
\hline Switzerland & 0.00 & 6.50 & 1.00 & 1.00 & 23.00 & 9.00 & 0.00 & 0.00 & NA \\
\hline Thailand & 6.00 & 4.00 & 1.00 & 1.17 & 3.00 & 2.00 & 1.00 & 0.00 & NA \\
\hline Turkey & 0.50 & 9.00 & 1.00 & 1.75 & 2.00 & 2.00 & 0.00 & 2.00 & 3.72 \\
\hline UK & 5.00 & 7.00 & 1.00 & 3.08 & 3.00 & 3.00 & 1.00 & 3.25 & 4.00 \\
\hline USA & 1.00 & 16.50 & 1.00 & 0.75 & 5.00 & 2.00 & 1.00 & 3.50 & 3.42 \\
\hline EZ & 0.25 & 14.50 & 1.00 & 4.08 & 14.00 & 5.00 & 1.00 & 2.75 & 4.87 \\
\hline
\end{tabular}


Table 3a - Macroprudential Timeliness and Credit Growth: Selected Results, Index Favour Decentralization

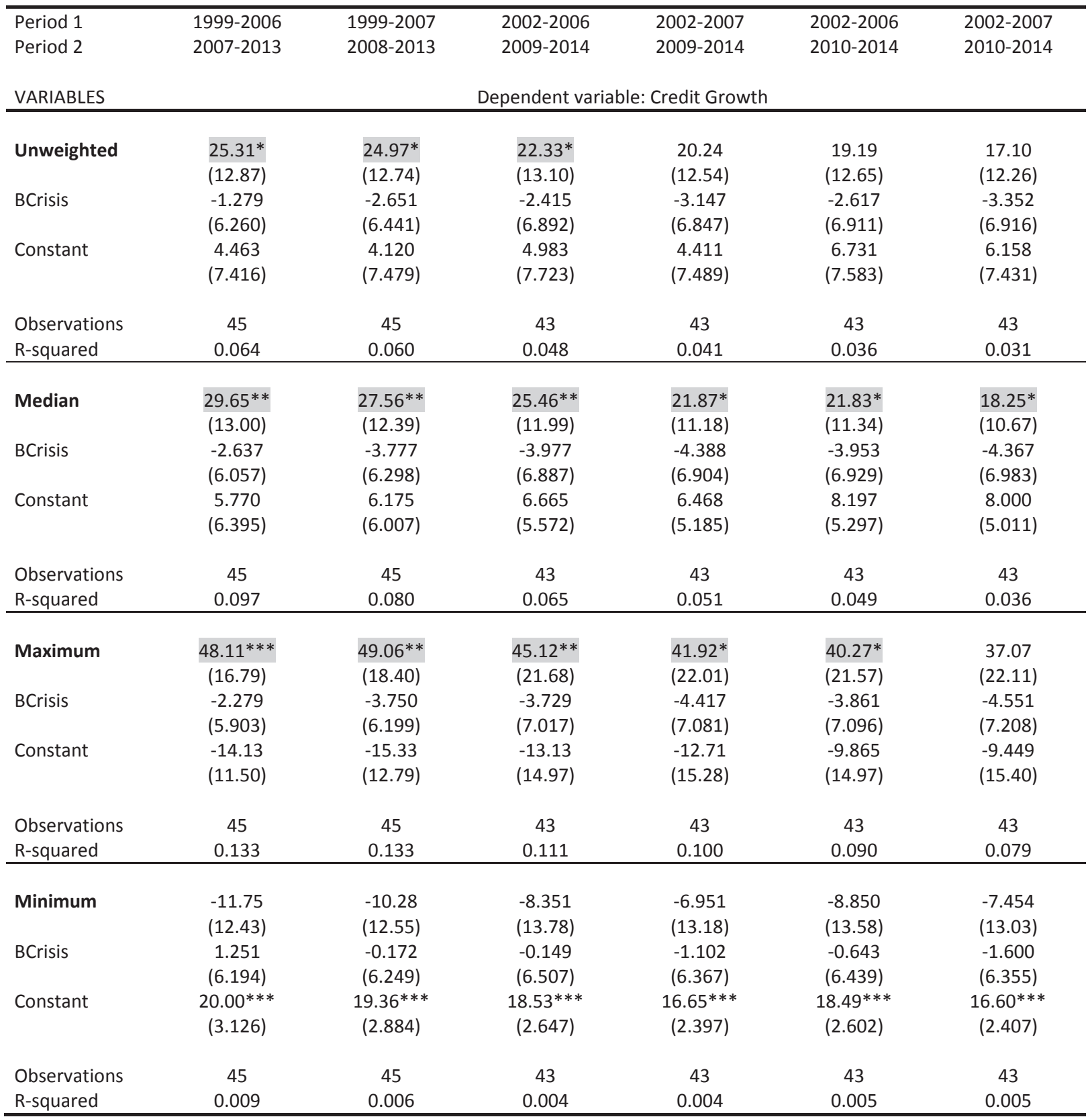

Note: Timeliness is as defined in Table 1. BCrisis is a banking crisis dummy (see text). Maximum is the most favourable (i.e., highest macroprudential capacity), Minimum is the least favourable. Results chosen from across seven different weighting schemes (see Figure 3 and the text). Highlighted values are statistically significant at least at the $10 \%$ level. The dependent variable is the growth of domestic credit to the private sector by banks as a percent of GDP. Robust standard errors in parentheses: $* * * \mathrm{p}<0.01$, $* * \mathrm{p}<0.05$, $* \mathrm{p}<0.1$. Decentralization refers to the number of institutions involved in carrying out macroprudential policies (see text). 
Table 3b - Macroprudential Timeliness and Credit Growth: Selected Results, Index Favour Centralization

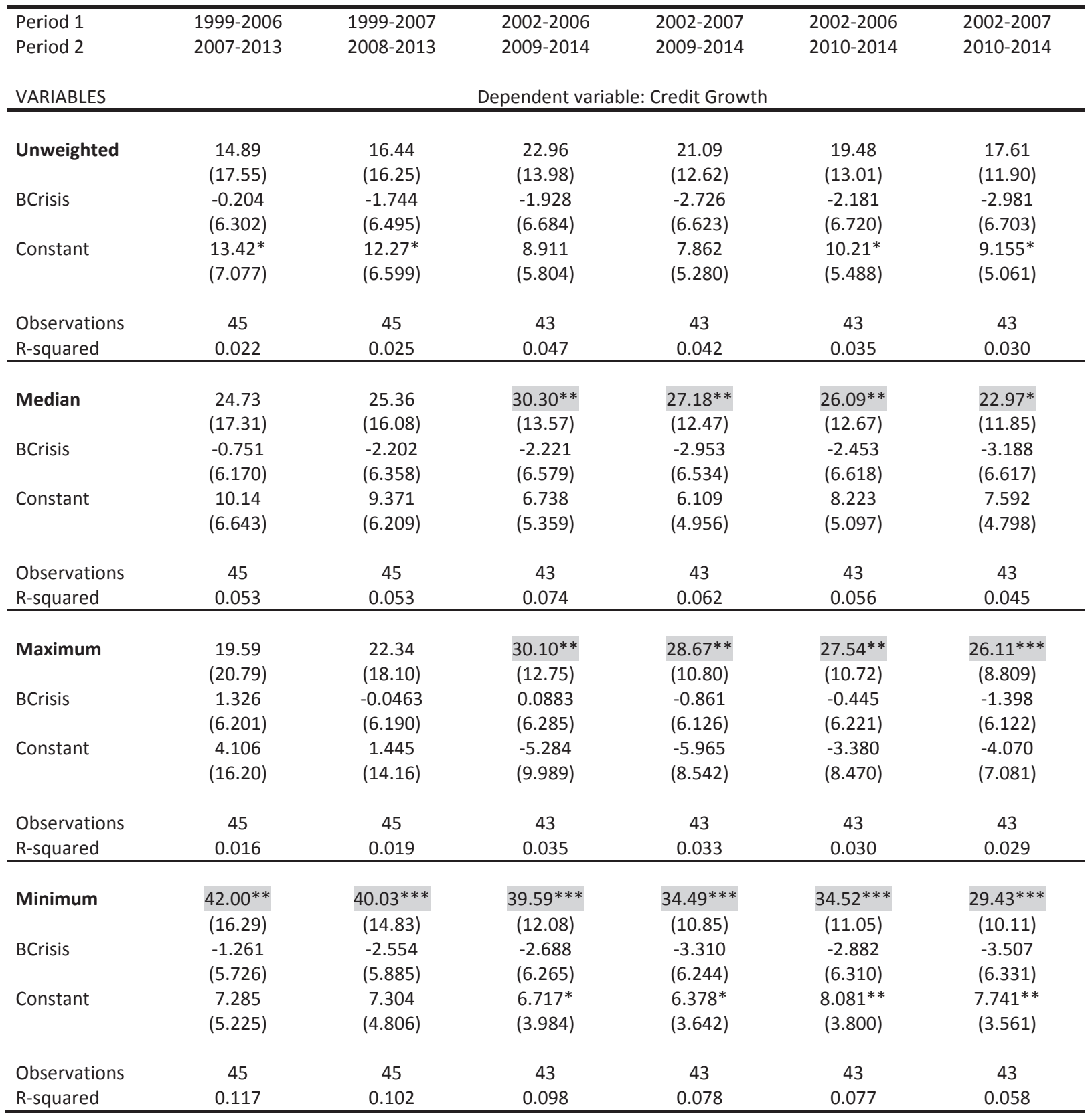

Note: see notes to Table 3a. 